\title{
Responses of crop yield, apparent potassium balance, and soil potassium status to long-term fertilization and lime addition in acidic Ultisol
}

Tianfu Han ${ }^{1}$, Dongchu Li $^{1}$, Kailou Liu ${ }^{1}$, Jing Huang ${ }^{1}$, Lu Zhang ${ }^{1}$, Xiao Yan Zhu ${ }^{2}$, Asad Shah $^{3}$, Shujun Liu ${ }^{1}$, Gu Feng ${ }^{2}$, Qaswar Muhammad ${ }^{1}$, Lisheng Liu ${ }^{1}$, zhang huimin ${ }^{1}$, and Boren Wang ${ }^{1}$

${ }^{1}$ Chinese Academy of Agricultural Sciences Institute of Agricultural Resources and Regional Planning ${ }^{2}$ China Agricultural University

${ }^{3}$ Chinese Academy of Agricultural Sciences

January 7, 2021

\begin{abstract}
Soil acidification is one of the major soil degradation phenomenon in tropical and subtropical region, which cause reductions in soil fertility, particularly potassium (K), and declines in crop yield. However, it remains unclear whether and how the status of $\mathrm{K}$ in soils and crops changes with the application of lime to alleviate soil acidification. Six treatments of long-term experiments (started 1990) in subtropical region were carried out. Regardless of fertilization regime, lime addition markedly increased grain and straw yields compared to those yields without lime application. Lime addition also led to significant decreases in the apparent $\mathrm{K}$ balances compared to soils without lime application. The agronomic K efficiency and partial factor productivity of $\mathrm{K}$ fertilizer both significantly increased after lime application. Lime addition reduced the soil exchangeable K (EK) content and stock, while increased soil non-exchangeable K (NEK) content and stock. Redundancy analysis showed that K input, lime, pH, and exchangeable calcium all significantly affected the $\mathrm{K}$ in soil and crops. Path analysis showed that lime indirectly influenced soil K (EK and NEK) by directly affecting soil pH, exchangeable calcium, K uptake and apparent K balances. These results suggest that lime addition is a viable strategy for improving crop yields and $\mathrm{K}$ fertilizer efficiency in degraded soils caused by acidification. Lime significant increased $\mathrm{K}$ uptake which lead to decreased soil EK content and stock. Additional, lime also increased soil NEK content and stock which was regulated by soil $\mathrm{pH}$, exchangeable calcium, and crop growth.
\end{abstract}

\section{Hosted file}

MS.pdf available at https://authorea.com/users/388025/articles/502881-responses-of-cropyield-apparent-potassium-balance-and-soil-potassium-status-to-long-term-fertilizationand-lime-addition-in-acidic-ultisol

\section{Hosted file}

Fig.pdf available at https://authorea.com/users/388025/articles/502881-responses-of-cropyield-apparent-potassium-balance-and-soil-potassium-status-to-long-term-fertilizationand-lime-addition-in-acidic-ultisol

\section{Hosted file}

Tables.pdf available at https://authorea.com/users/388025/articles/502881-responses-of-cropyield-apparent-potassium-balance-and-soil-potassium-status-to-long-term-fertilization- 
and-lime-addition-in-acidic-ultisol

\section{Hosted file}

Highlight.pdf available at https://authorea.com/users/388025/articles/502881-responsesof-crop-yield-apparent-potassium-balance-and-soil-potassium-status-to-long-termfertilization-and-lime-addition-in-acidic-ultisol 